\title{
Temporal shifts in top-down vs. bottom-up control of epiphytic algae in a seagrass ecosystem
}

\author{
MA Whalen \\ Virginia Institute of Marine Science \\ JE Duffy \\ Virginia Institute of Marine Science \\ JB Grace
}

Follow this and additional works at: https://scholarworks.wm.edu/vimsarticles

Part of the Marine Biology Commons

\section{Recommended Citation}

Whalen, MA; Duffy, JE; and Grace, JB, "Temporal shifts in top-down vs. bottom-up control of epiphytic algae in a seagrass ecosystem" (2013). VIMS Articles. 1732.

https://scholarworks.wm.edu/vimsarticles/1732

This Article is brought to you for free and open access by W\&M ScholarWorks. It has been accepted for inclusion in VIMS Articles by an authorized administrator of W\&M ScholarWorks. For more information, please contact scholarworks@wm.edu. 


\title{
Temporal shifts in top-down vs. bottom-up control of epiphytic algae in a seagrass ecosystem
}

\author{
Matthew A. Whalen, ${ }^{1,3}$ J. Emmett Duffy, ${ }^{1}$ and James B. Grace ${ }^{2}$ \\ ${ }^{1}$ Virginia Institute of Marine Science, College of William and Mary, P.O. Box 1346, Gloucester Point, Virginia 23062 USA \\ ${ }^{2}$ U.S. Geological Survey, National Wetlands Research Center, 700 Cajundome Boulevard, Lafayette, Louisiana 70506 USA
}

\begin{abstract}
In coastal marine food webs, small invertebrate herbivores (mesograzers) have long been hypothesized to occupy an important position facilitating dominance of habitatforming macrophytes by grazing competitively superior epiphytic algae. Because of the difficulty of manipulating mesograzers in the field, however, their impacts on community organization have rarely been rigorously documented. Understanding mesograzer impacts has taken on increased urgency in seagrass systems due to declines in seagrasses globally, caused in part by widespread eutrophication favoring seagrass overgrowth by faster-growing algae. Using cage-free field experiments in two seasons (fall and summer), we present experimental confirmation that mesograzer reduction and nutrients can promote blooms of epiphytic algae growing on eelgrass (Zostera marina). In this study, nutrient additions increased epiphytes only in the fall following natural decline of mesograzers. In the summer, experimental mesograzer reduction stimulated a $447 \%$ increase in epiphytes, appearing to exacerbate seasonal dieback of eelgrass. Using structural equation modeling, we illuminate the temporal dynamics of complex interactions between macrophytes, mesograzers, and epiphytes in the summer experiment. An unexpected result emerged from investigating the interaction network: drift macroalgae indirectly reduced epiphytes by providing structure for mesograzers, suggesting that the net effect of macroalgae on seagrass depends on macroalgal density. Our results show that mesograzers can control proliferation of epiphytic algae, that top-down and bottom-up forcing are temporally variable, and that the presence of macroalgae can strengthen top-down control of epiphytic algae, potentially contributing to eelgrass persistence.
\end{abstract}

Key words: direct vs. indirect effects; epiphyte; mesograzer; seagrass; structural equation modeling; top-down vs. bottom-up processes; trophic cascade; York River, Virginia, USA; Zostera marina.

\section{INTRODUCTION}

A fundamental question in ecology is how bottom-up and top-down processes interact within food webs to control structure and function of ecological systems. A key challenge is to anticipate how environmental change might modify these effects (Gruner et al. 2008). As primary consumers, herbivores occupy a central position in most food webs by linking primary producers and higher-order consumers, providing a conduit through which bottom-up and top-down effects are conveyed. In many aquatic and marine systems, the dominant herbivores are small invertebrates (mesograzers; Brawley 1992), which are important prey for fishes (Edgar and Shaw 1995, Taylor 1998) and have been implicated as intermediate links in trophic cascades (Duffy and Hay 2000, Duffy et al. 2005, Davenport and Anderson 2007). Field observations and experiments suggest that meso-

Manuscript received 30 January 2012; revised 27 August 2012; accepted 7 September 2012. Corresponding Editor: J. H. Grabowski.

${ }^{3}$ Present address: Department of Evolution and Ecology, University of California, One Shields Avenue, Davis, California 95616 USA. E-mail: mawhalen@ucdavis.edu grazers can have strong effects on primary production, trophic transfer, and biogeochemical cycling (Edgar and Aoki 1993, Edgar and Shaw 1995, Heck et al. 2000, Spivak et al. 2009). The difficulty of experimentally manipulating these small and abundant animals, however, has hampered realistic tests of these ideas.

Mesograzers may have especially important top-down effects in temperate seagrass beds, where they are often the dominant herbivores, consuming primarily epiphytic algae and detritus, and only rarely consuming seagrass directly (Cebrián 1999, Valentine and Duffy 2006). Seagrass systems provide many ecosystem services to humans (Costanza et al. 1997), including shoreline protection and nurseries for commercially important fisheries species (Williams and Heck 2001). Mesograzers are believed to facilitate seagrasses, and thus potentially associated ecosystem services, by reducing epiphytic algae that compete with seagrasses for light and other resources (Sand-Jensen 1977, van Montfrans et al. 1984). Since seagrasses are declining worldwide (Orth et al. 2006), often in concert with nutrient loading that can favor algal overgrowth (Hauxwell et al. 2001), clarifying these interactions has important implications for both practical conservation of seagrass systems as 
well as understanding a key link common to many aquatic food webs.

The role of grazing in structuring seagrass communities has remained unresolved for decades, largely because the small size, mobility, and challenging taxonomy of the dominant mesograzers have made field experimentation difficult. Mesocosm experiments clearly demonstrate the ability of mesograzers to control algal growth and ecosystem responses (reviewed by Valentine and Duffy 2006), but the relevance of mesocosm experiments to nature remains unclear (e.g., Carpenter 1996, 1999, Drenner and Mazumder 1999). Manipulations of mesograzers using cages avoids some problems associated with mesocosm studies, but field caging experiments have their own drawbacks, e.g., the few published field cage experiments (Nelson 1979, Heck et al. 2000, Worm et al. 2000, Douglass et al. 2007, Moksnes et al. 2008, Andersson et al. 2009) have often been subject to altered water flow, reduced light, and behavioral changes in higher order consumers (see Virnstein 1978, Connell 1997, Miller and Gaylord 2007). Moreover, the potentially complex interactions among physical forcing, nutrient loading, grazer abundance and species composition, and primary producers have never been satisfactorily disentangled. Thus, the importance of bottom-up and top-down forcing in seagrass systems remains controversial (Heck and Valentine 2006, 2007).

To test the influence of mesograzers on seagrasses and algae in the field, we adopted the innovative approach of Poore et al. (2009). These authors successfully manipulated mesograzers without cages and their associated artifacts in a kelp bed using the insecticide carbaryl, followed by Cook et al. (2011) who applied the approach to temperate Southern Hemisphere seagrass beds. We experimentally evaluated the roles of both herbivory and nutrient input in determining the relative dominance of primary producers in a natural eelgrass (Zostera marina) system during two seasons. Our goals were to (1) evaluate the impacts of mesograzers on primary producer biomass, production, and composition in natural field situations; (2) simultaneously compare bottom-up (nutrient loading) and top-down (grazing) processes in determining the balance between seagrass and algal dominance; and (3) investigate the temporal dynamics of direct and indirect effects of experimental manipulations in models of the system.

\section{Methods}

We conducted three field experiments to evaluate the top-down impacts of mesograzers by incorporating the degradable insecticide carbaryl (Bayer CropScience, Research Triangle Park, North Carolina, USA) into a slowly dissolving plaster matrix, allowing exclusion of mesograzers over a period of several weeks (Poore et al. 2009). Carbaryl is a reversible acetylcholinesterase inhibitor widely used against arthropods in homes and gardens in the United States (EPA 2011). It is also effective against aquatic arthropods, but has limited effects on non-arthropod taxa, including algae (Carpenter 1986, Duffy and Hay 2000, Dumbauld et al. 2001) and degrades rapidly (Armbrust and Crosby 1991), offering a promising means of deterring arthropods with little lasting effect on other organisms. Our first pilot experiment tested the effectiveness and range of the slow-release carbaryl deterrent method (Appendix A). The other two experiments factorially manipulated grazer deterrence and nutrient fertilization in two seasons (fall 2008 and summer 2009) to investigate top-down and bottom-up processes operating in a natural seagrass bed. In all three experiments, deterrent was deployed in slow-release blocks in the field by mixing wettable carbaryl powder $(80 \%$ carbaryl by mass) with cold water, incorporating it into dental plaster, and pouring the mixture into $100-\mathrm{mL}$ molds with a stainless steel wire loop to allow attachment to other objects. Blocks were allowed to harden overnight, removed from molds, and dried in a $60^{\circ} \mathrm{C}$ oven for $3 \mathrm{~d}$.

\section{Experimental manipulation of grazers and nutrients}

Two field experiments tested the effects of resource loading and grazing on primary producers by factorially manipulating nutrients and crustacean grazers in an eelgrass (Zostera marina) bed in the York River, Virginia, USA $\left(37^{\circ} 15^{\prime} \mathrm{N}, 76^{\circ} 25^{\prime} \mathrm{W}\right)$. Field plots were defined by a triangular array, $30 \mathrm{~cm}$ on a side, of PVC poles sunk into the sediment, with a deterrent or control block attached to each pole within the eelgrass canopy $\sim 20 \mathrm{~cm}$ above the sediment surface. Deterrent blocks incorporated $10 \%$ carbaryl by dry mass plaster in the fall experiment and $5 \%$ in the summer. To elevate watercolumn nutrients we deployed $300 \mathrm{~g}$ of the slow-release fertilizer Osmocote (N:P:K=19:6:12; Scotts, Columbus, Ohio, USA) in perforated PVC tubes (Spivak et al. 2009). See Appendix D for details on experimental nutrient fertilization. The control treatment received a plaster block without deterrent and an empty nutrient diffuser. Experimental plots were located randomly at a depth of $1 \mathrm{~m}$ at low tide and separated by $2 \mathrm{~m}$. In addition to the four combinations of deterrent and nutrient, the summer experiment included a fifth treatment consisting of a plot with no plaster block or nutrient diffuser. Each treatment was replicated 10 times in the fall and eight times in the summer. We ran the fall experiment for 24 days starting 20 October 2008 and the summer experiment for 38 days starting 18 June 2009. Nutrient diffusers and plaster blocks were replaced weekly. We obtained water temperature data every 15 minutes from the Virginia Institute of Marine Science's real time data buoy located at $37^{\circ} 14^{\prime} \mathrm{N}, 76^{\circ} 25^{\prime} \mathrm{W}$.

Mesograzers were sampled from the periphery of plots prior to treatment addition and at multiple dates after treatment addition, using a grab sampler modified from Virnstein and Howard (1987) that collects aboveground eelgrass and associated organisms from an area of bottom measuring $20 \times 25 \mathrm{~cm}$. Samples were stored at 
$-20^{\circ} \mathrm{C}$ until processing. Macrophyte material (i.e., eelgrass and macroalgae) was separated, dried at $60^{\circ} \mathrm{C}$, weighed, then combusted at $450^{\circ} \mathrm{C}$ and reweighed to obtain ash-free dry mass (AFDM). Mesograzers were identified, usually to species, enumerated, and abundance was standardized to macrophyte AFDM (hereafter, mesograzer density). On the same dates when mesograzers were sampled, we estimated micro-algal epiphyte biomass (hereafter, epiphyte biomass) on a single eelgrass shoot from the periphery of each plot using chlorophyll $a$ as a proxy, according to previously described methods (Douglass et al. 2010). Chlorophyll $a$ biomass was normalized to eelgrass leaf area sampled.

We quantified two metrics of eelgrass performance during the summer experiment, leaf growth and shoot density. Leaf growth was measured using a hole-punch technique in which extension of young, growing leaves is measured relative to old, senescent leaves (Zieman 1974). Shoots were harvested one week after punching and new growth was removed, dried at $60^{\circ} \mathrm{C}$, and weighed to determine dry mass (g DM per week). Because a response in leaf growth was expected to lag behind increases in epiphyte fouling due to treatment effects, we began marking shoots after treatments were applied. We marked one shoot from the periphery of every experimental plot at weeks three through five. We quantified shoot density as the number of eelgrass shoots present within experimental plots, counted once prior to the experiment and again at the end, and calculated proportional change in shoot density as $\left(N_{\mathrm{f}}-\right.$ $\left.N_{\mathrm{i}}\right) / N_{\text {i }}$, where $N_{\mathrm{i}}$ and $N_{\mathrm{f}}$ are initial and final number of eelgrass shoots, respectively, within a plot. In order to prevent resource translocation through rhizomes from areas of vegetative growth outside of the influence of experimental treatments or between plots, we severed rhizomes surrounding a $1-\mathrm{m}^{2}$ quadrat that was placed over each plot on a weekly basis.

\section{Statistical analyses and modeling}

We tested for effects of fertilization, grazer deterrence, and time on mesograzer density and epiphyte biomass using factorial three-way ANOVAs for each experiment separately ( $\mathrm{R}$ Development Core Team 2011). Data from samples taken prior to establishment of treatments were not used in the analyses. We treated time as a threelevel factor (three sampling dates) in models of mesograzers from the fall experiment and as a two-level factor (two sampling dates) for mesograzers in the summer and for epiphyte biomass in both fall and summer. We report analysis of the first 24 days from the summer experiment to aid comparison of the fall and summer experiments (see Appendix $\mathrm{C}$ for analysis of the full summer time series).

Treatment effects on eelgrass leaf growth were analyzed using repeated-measures ANOVA and within-plot correlations through time were accounted for by fitting models with different correlation structures. Models were fit in $\mathrm{R}$ using generalized least squares with the function "gls" in the package "nlme" (Pinheiro and Bates 2000), and we selected correlation structures using Akaike's Information Criterion. We analyzed shoot density using two-way ANOVA to test for additive and interactive effects of fertilization and grazer deterrence.

We employed structural equation modeling (SEM) to quantify temporal shifts in direct and indirect effects in models of experimental treatments, as well as natural variation in macrophyte biomass, on mesograzers and epiphytes during the summer experiment (Grace 2006, Grace et al. 2012). We chose the SEM framework because we were interested in understanding how net treatments effects were mediated by community interactions and to what extent these interactions changed during the experiment. Based on prior work (reviewed in Valentine and Duffy 2006), we hypothesized that (1) macrophytes (composed of eelgrass and the red macroalgae Gracilaria spp. and Agardhiella spp.) facilitate mesograzers through habitat provisioning; (2) nutrient fertilization directly enhances accumulation of algal epiphytes; and (3) mesograzers reduce epiphyte accumulation on eelgrass. These hypotheses are represented by the paths in the model. We present results from two models fitted to data from days 10 and 24 of the summer experiment using the software AMOS version 18 (Arbuckle 2009; see Appendix E for additional model description). All continuous variables in the models were log-transformed, which both improved normality and helped to linearize relationships. We report unstandardized coefficients and coefficients standardized on the ranges observed in the data (Grace and Bollen 2005). For log-transformed variables, unstandardized coefficients represent the expected percentage change in the response variable with a one percent change in the predictor. For paths involving the grazer deterrent and nutrient fertilization treatments, which were binary $(0,1)$ variables, the unstandardized coefficient represents the magnitude of effect of the treatment on the mean response. Range standardization of variables allows for comparison of different pathways in structural equation models using the range observed in the data as the context and describes the percentage change in the observed range of the response as the predictor increases across its range (Grace and Bollen 2005).

Modification of the original model was based on our knowledge of the natural history of the system, expectations from ecological theory, and statistical results (Grace 2006). In this case, when path coefficients were not significantly different from zero, paths were removed from the model. Also, we examined residual covariances between variables to decide whether additional pathways might be warranted. We assessed model fit with a $\chi^{2}$ test of the hypothesis that observed and estimated covariance matrices were equal. Because this test is based on large sample theory, the results, including both path coefficient estimates and significance, were confirmed using the Markov chain Monte 


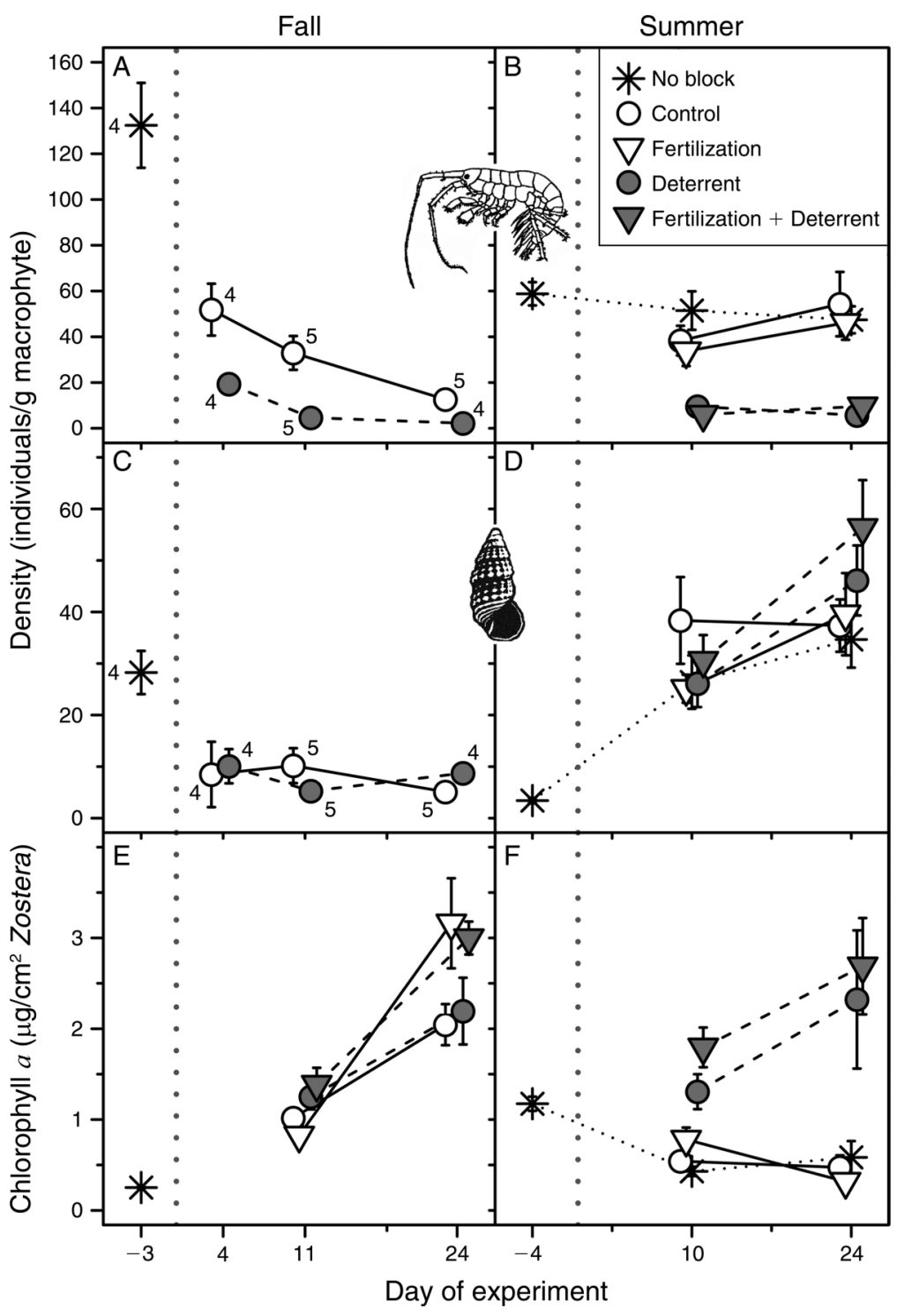

FIG. 1. Comparison of responses (mean $\pm \mathrm{SE}$ ) of $(\mathrm{A}, \mathrm{B})$ crustacean mesograzers, $(\mathrm{C}, \mathrm{D})$ gastropod mesograzers, and (E, F) epiphyte biomass (using chlorophyll $a$ as a proxy) to treatments in fall and summer experiments in an eelgrass (Zostera marina) bed in the York River, Virginia, USA. Osmocote fertilizer and carbaryl deterrent were applied to $390-\mathrm{cm}^{2}$ plots in a factorial design. For ease of comparison, the final sampling period from the summer experiment was removed (see Appendix C for full results). Points are jittered to reduce overlap. Dotted vertical lines denote the first day of each experiment. Sample sizes for mesograzers during the fall experiment are listed on the figure. All other sample sizes comprised full replication of the respective experiments (see Methods). No-block controls were not included in the analysis.

Carlo (Bayesian) techniques implemented in the Amos software (Lee and Song 2004, Lee 2007). We deemed paths nonsignificant if $95 \%$ credible intervals included zero.

\section{RESUlTs}

Carbaryl decreased the density of crustacean mesograzers in both fall and summer experiments, but the background trends in density were very different (Fig. $1 \mathrm{~A}, \mathrm{C}$, Table 1). In the fall, crustacean mesograzer density in control treatments decreased by $>90 \%$ in 27 days (Fig. 1A), while over the same time period in the summer, crustacean density showed no change in treatments without deterrent (Fig. 1B). In the fall experiment only a subset of mesograzer samples were sorted because the observed declining trend was easily distinguished statistically. Over the course of the entire six-week summer experiment, carbaryl decreased the density of crustacean mesograzers by $46-84 \%$, with the strongest effect on gammarid amphipods (Appendix C: Fig. C1, Tables $\mathrm{C} 1$ and $\mathrm{C} 2$; see Plate 1). A single ANOVA was performed on density of pooled crusta- 
TABLE 1. Univariate analyses of mesograzer densities and epiphyte biomass from (A) fall and (B) summer experiments in an eelgrass (Zostera marina) bed in the York River, Virginia, USA.

\begin{tabular}{|c|c|c|c|c|c|c|c|c|c|}
\hline \multirow{2}{*}{$\begin{array}{l}\text { Experiment and } \\
\text { response source }\end{array}$} & \multicolumn{3}{|c|}{ Crustaceans } & \multicolumn{3}{|c|}{ Gastropods } & \multicolumn{3}{|c|}{ Epiphytes } \\
\hline & $\mathrm{df}$ & $F$ & $P$ & $\mathrm{df}$ & $F$ & $P$ & $\mathrm{df}$ & $F$ & $P$ \\
\hline \multicolumn{10}{|l|}{ A) Fall } \\
\hline Deterrent & 1 & 42.84 & $<0.001$ & 1 & 0.33 & 0.574 & 1 & 3.97 & 0.052 \\
\hline Fertilization & & & & & & & 1 & 3.10 & 0.084 \\
\hline Sampling date & 2 & 13.77 & $<0.001$ & 2 & 0.12 & 0.887 & 1 & 78.24 & $<0.001$ \\
\hline Det. $\times$ fert. & & & & & & & 1 & 0.86 & 0.358 \\
\hline Det. $\times$ date & 2 & 2.48 & 0.108 & 2 & 1.27 & 0.301 & 1 & 3.72 & 0.059 \\
\hline Fert. $\times$ date & & & & & & & 1 & 7.00 & 0.011 \\
\hline Det. $\times$ fert. $\times$ date & & & & & & & 1 & 0.81 & 0.371 \\
\hline Residual & 21 & & & 21 & & & 51 & & \\
\hline \multicolumn{10}{|l|}{ B) Summer } \\
\hline Deterrent & 1 & 129.24 & $<0.001$ & 1 & 1.07 & 0.306 & 1 & 66.22 & $<0.001$ \\
\hline Fertilization & 1 & 0.00 & 0.958 & 1 & 0.01 & 0.920 & 1 & 2.19 & 0.145 \\
\hline Sampling date & 1 & 0.89 & 0.349 & 1 & 11.00 & 0.002 & 1 & 0.83 & 0.367 \\
\hline Det. $\times$ fert. & 1 & 0.10 & 0.756 & 1 & 2.00 & 0.163 & 1 & 1.00 & 0.322 \\
\hline Det. $\times$ date & 1 & 0.58 & 0.448 & 1 & 2.96 & 0.091 & 1 & 6.21 & 0.016 \\
\hline Fert. $\times$ date & 1 & 2.90 & 0.094 & 1 & 0.71 & 0.403 & 1 & 0.53 & 0.468 \\
\hline Det. $\times$ fert. $\times$ date & 1 & 1.57 & 0.216 & 1 & 0.27 & 0.606 & 1 & 1.14 & 0.290 \\
\hline Residual & 56 & & & 56 & & & 56 & & \\
\hline
\end{tabular}

Notes: ANOVA tables for linear models describe the effects of chemical deterrent, nutrient fertilization, and sampling date on crustacean mesograzer density, gastropod mesograzer density, and epiphyte biomass. All data were natural-log-transformed except summer gastropods (square-root transformed). Model terms were tested using $F$ tests and type III sums of squares. Note that the analyses presented for the summer experiment are balanced. $P$ values $<0.05$ are shown in boldface.

cean mesograzers rather than separately for each taxonomic group (i.e., gammarid and caprellid amphipods, isopods) because zero densities were common within crustacean taxonomic groups, but were nonexistent when crustaceans were pooled, and because patterns were similar across crustacean taxa (Appendix C: Fig. C1A-C). Gastropod mesograzers (represented solely by Bittium varium) were unaffected by deterrent in both experiments (Fig. 1C, D, Table 1). Gastropod densities were low during the fall experiment, but were much higher in the summer. Nutrient fertilization did not statistically affect the density of any mesograzer taxon in either fall or summer based on our univariate models. See Appendices B and C for additional faunal results.

Epiphyte biomass responses to experimental treatments were markedly different between the fall and summer. During the fall experiment, epiphyte biomass increased in all treatments through time (Fig. 1E, Table 1 ), presumably in response to the decline of mesograzers. This increase was stronger in fertilized treatments, such that fertilization increased epiphyte biomass at day 24 (fertilization $\times$ sampling date, $P=0.011$ ), when mesograzers were nearly absent. We found no significant effect of deterrent on epiphyte biomass during the fall, but there was a trend toward higher epiphyte biomass in deterrent plots at day 11 relative to control plots.

During the summer experiment, epiphyte biomass also increased but this increase was seen only in response to deterrent treatment (Fig. 1F; $P<0.001$ ), which stimulated a $289 \%$ increase in epiphyte biomass averaged across the first two sampling dates. Epiphyte biomass was $166 \%$ higher in deterrent treatments on day
10, but had grown to $447 \%$ higher by day 24 (Fig. 1F), reflecting a significant deterrent $\times$ time interaction (Table 1; $P=0.016$ ). Epiphyte biomass declined nonlinearly with density of crustacean mesograzers (Fig. 2; Appendix C: Table C3). Nutrient fertilization did not significantly affect epiphyte biomass at any time during the summer experiment, although there was a nonsignificant trend toward higher epiphyte biomass in plots receiving both deterrents and fertilizer at day 10 that largely disappeared by day 24 .

Eelgrass leaf growth declined significantly through time in all treatments in the summer experiment (Fig. $3 \mathrm{~A}$, Table 2). The trend in leaf growth rate was inversely related to that of water temperature during the preceding week (Pearson's $r=-0.90$ ), presumably reflecting thermal stress and late summer senescence experienced by Zostera marina populations in Chesapeake Bay (Orth and Moore 1986, Moore and Jarvis 2008). Similarly, eelgrass shoot density within experimental plots was on average lower at the end of the experiment than during the preliminary sampling. However, shoot density declined significantly more within grazer deterrent plots than control plots (Fig. 3B, Table 2).

The finalized structural equation models fit the data from each time point well (Fig. 4; Appendix E: Table E1) and allowed us to simultaneously examine how mesograzer groups mediated net effects of treatments on epiphytes as well as how macrophytes affected mesograzers and epiphytes. We chose to analyze two sampling dates, days 10 and 24, because neither had missing data for any variable (two epiphyte samples were lost in the field on day 38) and because we observed 
weaker relationships at the end of the experiment, potentially due to eelgrass senescence mentioned in the previous paragraph (Figs. 2 and 3). Nutrient fertilization had no direct effect on epiphytes in our structural equation models, refuting our hypothesis 1 , but it positively influenced isopods on day 24 (Fig. 4). Gastropods were not included in our models because we did not directly manipulate gastropod density and gastropods showed no relationship with epiphyte biomass.

Grazer deterrent treatment had consistently positive effects on epiphyte biomass. On day 10, the deterrent treatment effect, as represented in the model, was indirect and mediated entirely by gammarid and caprellid amphipods (Fig. 4A). Fourteen days later, however, mediation by grazers was lost and epiphyte biomass depended solely on a "direct" effect of deterrent (Fig. 4B). A single model incorporating data from both days 10 and 24 (presented in Appendix E) shows that epiphyte biomass at day 24 depended on epiphyte biomass at day 10, and thus the effect of deterrent on epiphytes in the model for day 24 was actually mediated by community interactions operating at both time steps. The relationship between epiphyte biomasses on different dates in the model clearly illustrates that the mesograzer reduction early in the experiment set the stage for later algal accumulation, despite an apparent reduction or loss of interactions between mesograzers and epiphytes at day 24 (Fig. 4B; Appendix E: Fig. E6).

The relationships between macrophytes (i.e., eelgrass and macroalgae) and downstream variables showed both transitory and persistent effects. Both macroalgae and seagrass increased epiphyte biomass independently of mesograzers at day 10, but these effects disappeared by day 24 (Fig. 4). Throughout the entire experiment, both groups of macrophytes increased mesograzer abundance, supporting hypothesis 1 (Fig. 4; Appendix C: Fig. C5). Unexpectedly, however, macroalgal biomass was at least as good at predicting the abundance of crustacean mesograzer groups as was eelgrass biomass. As a result, macroalgae had stronger indirect effects on epiphytes than eelgrass in the model (Fig. 4; Appendix E).

\section{Discussion}

Natural history suggests that small grazing invertebrates are pivotal links in aquatic food webs, mediating both bottom-up transfer of production to fishes and topdown control of community organization, yet their potential top-down impacts have proven difficult to confirm in the field. Additionally, the relative importance of bottom-up and top-down control in seagrass systems is controversial (Heck and Valentine 2006, 2007, Valentine and Duffy 2006). Our study confirms that small, but abundant, herbivores can control the abundance of epiphytes growing on eelgrass in natural field settings, but more importantly, that the dominant factor controlling epiphyte abundance (i.e., bottom-up

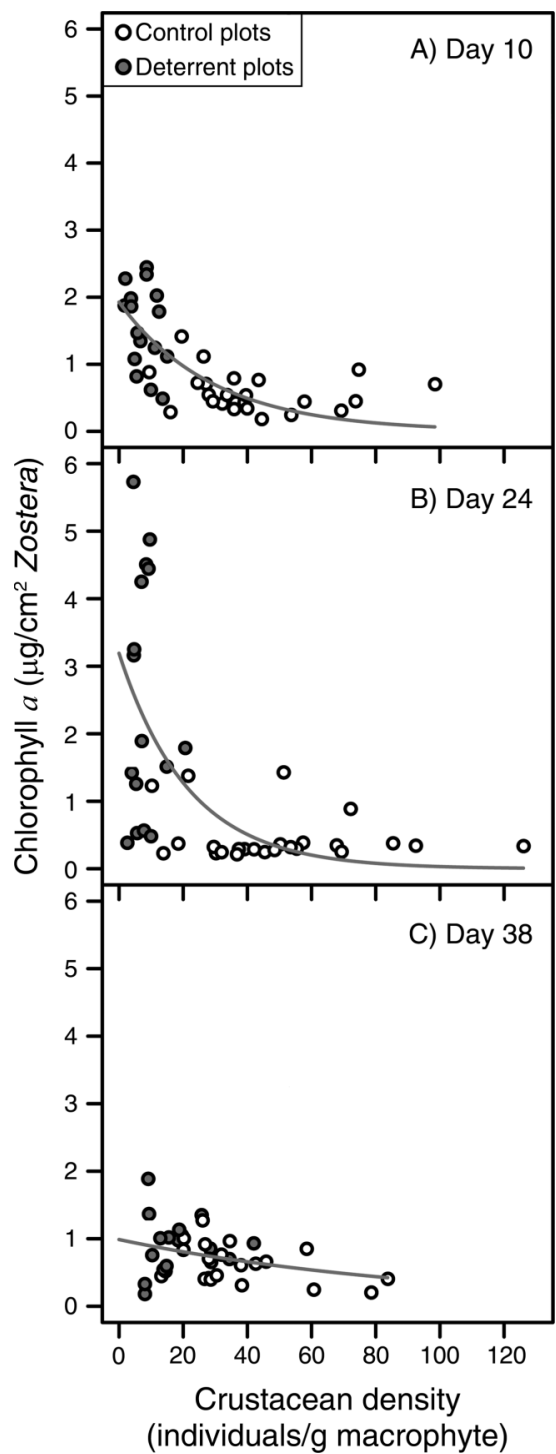

FIG. 2. Bivariate relationships between crustacean mesograzer density and epiphyte biomass (using chlorophyll $a$ as a proxy) at each sampling day of the summer experiment. Solid and open symbols correspond to deterrent and control plots, respectively. Lines show exponential curves fitted to data at each sampling date. See Appendix C for model fit measures.

or top-down) shifted between field experiments conducted in different seasons. In the fall experiment, the natural decline of mesograzers led to a bottom-up controlled state in which nutrient fertilization increased epiphyte biomass. In the summer, slow-release chemical deterrence nearly eliminated crustacean mesograzers for several weeks, stimulating a dramatic bloom of algae and acceleration of the seasonal decline in seagrass shoot density. Two previous studies have used chemical deterrent to successfully exclude mesograzers in the field for extended periods of time. The first study showed no effect of mesograzers on the epiphytes of a brown macroalga (Poore et al. 2009), while the second study 

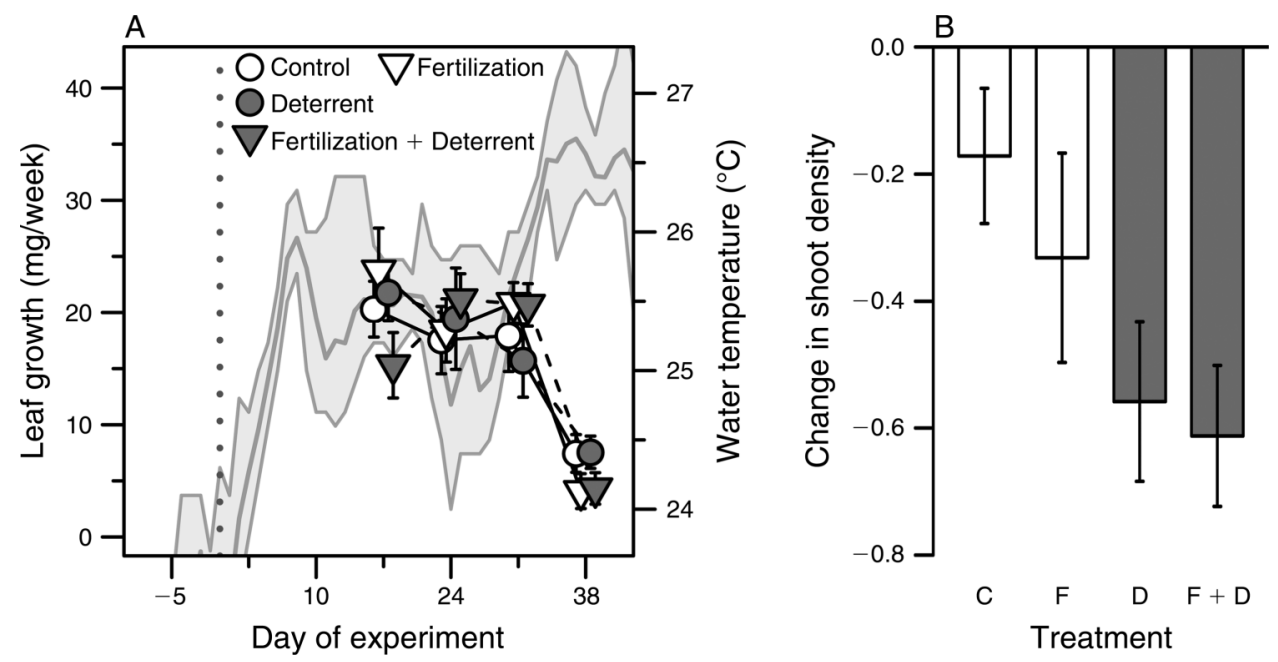

FIG. 3. Eelgrass performance responses (mean $\pm \mathrm{SE}$ ) to treatments in the summer experiment. (A) Leaf growth rate, with treatment symbols as in Fig. 1. Gray lines are minimum, maximum, and mean daily water temperature during the experiment. The dotted vertical line denotes the first day of the experiment on 20 June 2009. (B) Proportional change in eelgrass shoot density (mean $\pm \mathrm{SE}$ ) by treatment: $\mathrm{C}$, control; F, nutrient fertilization; D, grazer deterrent; F + D, fertilization + deterrent.

showed that lower mesograzer densities increased the biomass of epiphytes in one seagrass habitat (formed by Posidonia sinuosa) but not another (Amphibolis spp.; Cook et al. 2011). In neither study were nutrients manipulated nor did mesograzer reduction appear to have indirect effects on the foundation species.

Our field experimental results complement and are largely consistent with previous studies, mostly from mesocosms, demonstrating effective control of epiphytic algae by mesograzers in seagrass communities (Hughes et al. 2004, Valentine and Duffy 2006). Among the major mesograzer taxa in our eelgrass community, amphipods showed the strongest negative relationships with epiphytes, suggesting that they are the most important consumers of primary production, and the most influential grazers. In contrast, deterrent had no effect on gastropods, yet algae bloomed profusely despite increasing gastropod densities in the summer experiment. That algae bloomed dramatically despite the continued presence of abundant gastropods suggests that the latter have little ability to control algae in this system. Because herbivorous amphipods are ubiquitous in coastal systems and are important prey items for higher-order consumers, they likely play similarly important roles in many other coastal food webs (Valentine and Duffy 2006).

The exponential decline in epiphytic algae with increasing crustacean density in the summer experiment suggests that even relatively low densities of mesograzers can control algal accumulation (Fig. 2). Indeed, by day 24 the relationship between mesograzer abundance and epiphyte biomass appeared to depend more on a binary effect of treatment (grazer deterrent vs. control) than on crustacean density per se (Figs. 2B and 4B). Algal escape from grazer control in the fall experiment corresponded to the threshold for grazer control observed in the summer experiment $(\sim 20$ crustaceans/g macrophyte; Figs. 1 and 2), consistent with a minimal abundance of

TABLE 2. Analysis of eelgrass performance metrics from the summer experiment.

\begin{tabular}{|c|c|c|c|c|c|c|}
\hline \multirow[b]{2}{*}{ Response source } & \multicolumn{3}{|c|}{ Leaf growth $\dagger$} & \multicolumn{3}{|c|}{ Shoot density } \\
\hline & df & $F$ & $P$ & df & $F$ & $P$ \\
\hline Deterrent & 1 & 0.02 & 0.899 & 1 & 6.68 & 0.015 \\
\hline Fertilization & 1 & 0.00 & 0.995 & 1 & 1.24 & 0.275 \\
\hline Sampling date & 3 & 32.98 & $<0.001$ & & & \\
\hline Det. $\times$ fert. & 1 & 0.63 & 0.432 & 1 & 0.10 & 0.751 \\
\hline Det. $\times$ date & 3 & 0.70 & 0.555 & & & \\
\hline Fert. $\times$ date & 3 & 0.27 & 0.845 & & & \\
\hline Det. $\times$ fert. $\times$ date & 3 & 2.32 & 0.083 & & & \\
\hline Residual & 65 & & & 28 & & \\
\hline
\end{tabular}

Notes: Model terms for leaf growth were tested using Wald tests for repeated-measures ANOVA and terms for shoot density were tested using $F$ tests. Wald and $F$ tests were calculated using type III sums of squares.

$\dagger$ Raw data, autoregressive covariance with heterogeneous variances.

† Box-Cox transformation. 

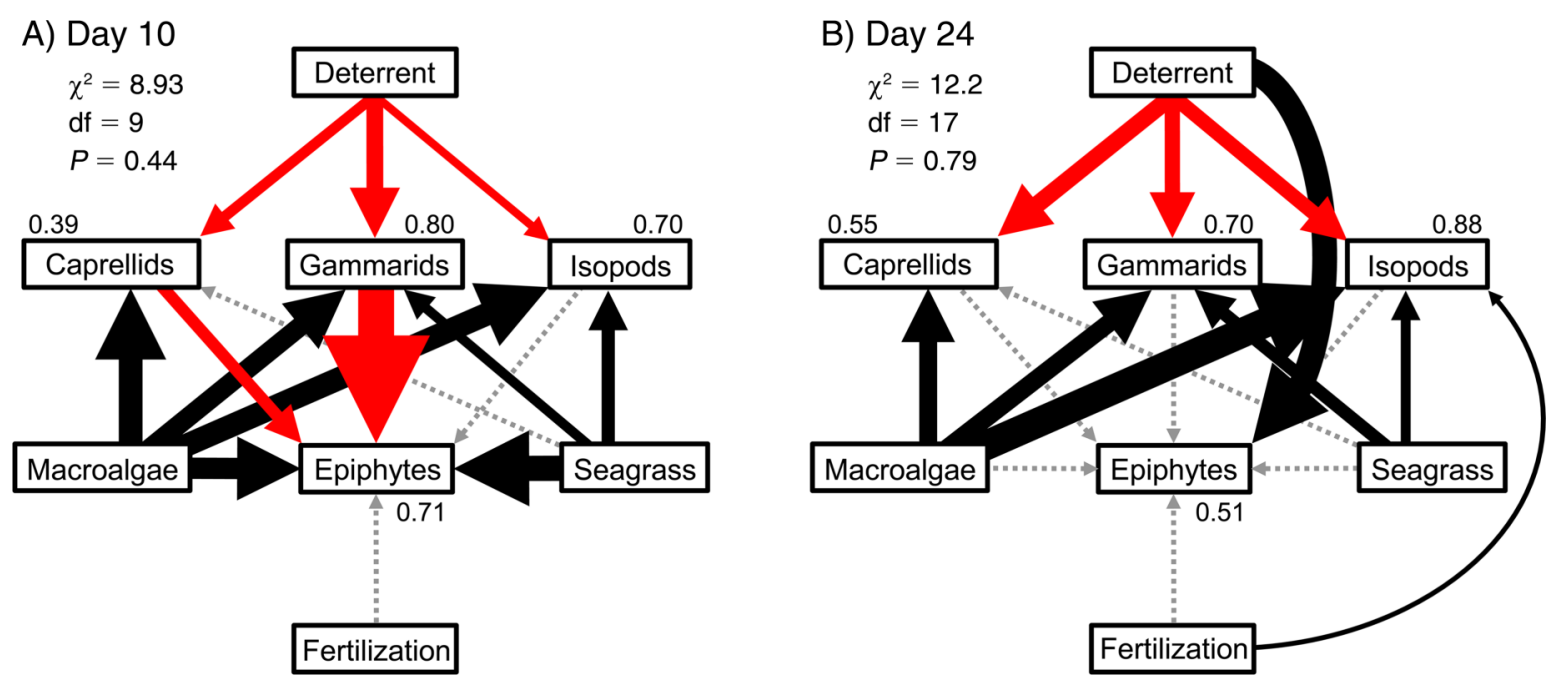

FIG. 4. Finalized structural equation models fitted separately to data from days 10 and 24 of the summer experiment. Black and red arrows denote positive and negative path coefficients, respectively. Dashed arrows represent nonsignificant paths that were removed from the final models. Arrow widths are proportional to standardized path coefficients. Path coefficients are standardized on the observed range and represent the percentage change in the range of the response as the predictor increases across its range. $R^{2}$ values are displayed above endogenous variables (i.e., variables with paths leading to them).

grazers required to suppress algal accumulation. In contrast, fertilization increased epiphyte biomass only in the fall experiment when top-down control by mesograzers declined below this threshold (Fig. 1), consistent with the results of previous experiments in which nutrient effects on epiphytes were only significant when grazers were absent or depleted (Neckles et al. 1993, reviewed in Heck and Valentine 2006). In the summer experiment, fertilization directly enhanced isopod abundance (Fig. 4B). Together with experimental evidence that nutrient fertilization can enhance mesograzer abundance without affecting algal biomass in this system (Spivak et al. 2009), these results suggest both strong top-down effects of crustacean grazers and efficient trophic transfer of primary production up the food chain when mesograzers are abundant.

Results of structural equation modeling confirmed the indirect effects of deterrent and macrophytes on epiphyte biomass in models of the system and identified the individual grazer taxa responsible for mediating those indirect effects. Our model also tested the bottomup effect of naturally varying abundances of macrophytes on grazer and eelgrass-associated epiphyte abundance (hypothesis 1). Both seagrass and macroalgae promoted crustacean mesograzers in our model and had negative indirect effects on epiphytes. Unexpectedly, however, we found that macroalgae was at least as important as eelgrass in promoting crustacean mesograzers (Appendix C: Fig. C5). Eelgrass-associated epiphytes may thus be inhibited as macroalgae drift into the eelgrass canopy and mobile consumers leave the safety of the macroalgae to forage on eelgrass epiphytes. Indeed, macroalgae indirectly reduced eelgrass epiphytes to a similar degree as the indirect effects of eelgrass on its epiphytes (Fig. 4; Appendix E). Direct effects of macrophytes on epiphytes, on the other hand (Fig. 4A; Appendix E: Fig. E6), could involve physical buffering of the water column, potentially providing loosely attached epiphytes (e.g., diatoms) with a more stable growing surface.

Support for negative indirect interactions between macroalgae and epiphytes suggests that the presence of macroalgae in this system can enhance top-down control of epiphyte biomass and that macroalgae may confer indirect positive effects on seagrass when at relatively low density. It is well-understood that macroalgal blooms can harm seagrasses (e.g., Hauxwell et al. 2001), and there are a few documented cases in which macroalgae outcompeted seagrasses and came to dominate systems with increasing nutrient loading (Hauxwell et al. 2001, Cardoso et al. 2004). We suggest that intermediate levels of nutrient loading may increase producer diversity (i.e., coexistence of macroalgae and seagrass) and enhance both top-down control of epiphytes and trophic transfer to higher order consumers.

Our findings provide the strongest support to date for the hypothesis that crustacean mesograzers and seagrasses exist in a mutualistic relationship (Valentine and Duffy 2006). Eelgrass significantly promoted crustacean mesograzer abundance throughout our summer experiment (Fig. 4; Appendix C: Fig. C4), consistent with many other studies showing the influence of seagrass structure on animals (e.g., Orth et al. 1984, Virnstein and Howard 1987). On the other side of the mutualism, mesograzer reduction significantly accelerated eelgrass decline during summer (Fig. 3B), presumably by relaxing grazer control of epiphytic algae, which overgrew the eelgrass. An alternative hypothesis is that 


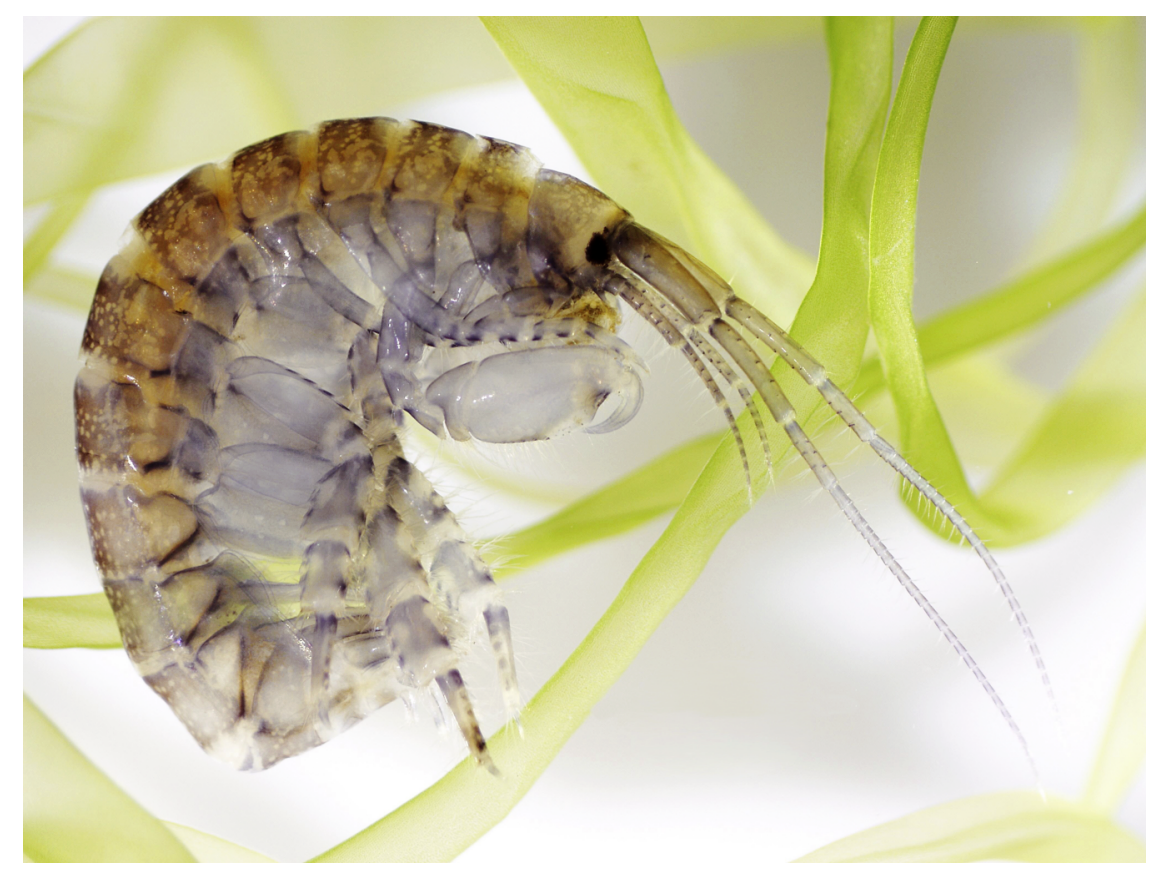

Plate 1. Elasmopus levis, a common gammarid amphipod mesograzer from the summer experiment (Appendix C: Table C2). The palatable green alga Ulva intestinalis is in the background. Photo credit: M. A. Whalen.

carbaryl directly reduced eelgrass growth, but previous work suggests that carbaryl has no effect on marine primary producers (Carpenter 1986, Duffy and Hay 2000), and two recent mesocosm experiments in our system similarly found no direct influence of carbaryl on eelgrass growth (P. L. Reynolds and J. P. Richardson, unpublished data), strongly implicating a facilitative role for amphipods in maintaining healthy eelgrass. Although the mechanism accelerating shoot decline is not definitively documented, our finding is consistent with work showing that increased epiphyte loads promote shedding of seagrass leaves (Howard and Short 1986, Orbita and Mukai 2009) and that amphipod reduction increases such epiphyte loading. The long-term effects of our experimental perturbation on eelgrass are also unclear, but it is plausible that an interaction between temperature and epiphyte stress could exacerbate summer dieback of eelgrass in Chesapeake Bay and limit its recovery in the following fall or spring. Our results underscore the significance of inconspicuous invertebrates in maintaining essential structure and functioning of this important ecosystem type, which highlights the need to consider herbivore abundance and species composition in efforts to manage and conserve seagrasses and associated animals harvested for human consumption.

Our finding that trophic control shifted across our experiments shows that bottom-up and top-down processes are temporally variable in our system. Bottom-up and top-down processes have been investigated heavily in seagrass systems (reviewed in Valentine and Duffy 2006) but the importance of these processes in determining the health and persistence of seagrass beds remains controversial (Heck and Valentine 2006, 2007). Our finding that these processes fluctuate in time may partly explain this controversy. At the very least, we have demonstrated that seasonal context can determine the outcome and interpretation of field trophic manipulations in seagrass beds.

The importance of mesograzers in our study mirrors the strong top-down pressure that appears to be widespread in benthic marine systems (Shurin et al. 2002, Gruner et al. 2008), but the differences we observed between two experiments shows that the relative strength of forcing originating from the top and bottom of food webs is variable in time. However, the lack of consistent bottom-up effects of nutrient enrichment in our experiments does not discount the known importance of nutrient loading in structuring marine communities (e.g., Cloern 2001). Rather, it may reveal that top-down and bottom-up processes operate on different scales, such that localized and relatively short-term perturbations that are the cornerstone of experimental ecology better capture the more rapid response - in this case, population dynamics of strongly interacting herbivores. This scale dependence emphasizes the need for large-scale, long-term field manipulations underpinned by sound understanding of the mechanisms underlying interactions and the history of natural systems. Additionally, the strong relationships we observed among mesograzers, seagrass, macroalgae, and epiphytic algae indicate that important feedbacks can exist between primary producers and the organisms they support that influence the strength of top-down 
processes and therefore the structure of producer assemblages and the functioning of ecosystems.

\section{ACKNOWLEDGMENTS}

J. G. Douglass and three anonymous reviewers provided comments that improved this manuscript. We thank J. P. Richardson, R. E. Blake, J. S. Lefcheck, A. F. P. Moore for assistance with setting up, maintaining, and sampling experimental plots; and M. S. Arencibia, E. Enriquez Hesles, J. A. New, Z. D. Pierson, and C. T. Rudebusch for assistance with processing mesograzer samples. R. M. Dickhut, M. C. Fabrizio, R. J. Latour, and R. J. Orth provided valuable input on experimental design and analysis. This is Contribution Number 3249 of the Virginia Institute of Marine Science, College of William and Mary. Mention of product names does not imply endorsement by the Government. This work was supported by grants from the National Science Foundation to J. E. Duffy (NSF OCE-1031061). Additional support for M. A. Whalen was provided by VIMS and by an NSF GK-12 grant to VIMS. Support for J. B. Grace was provided by funding from the USGS Climate Change and Ecosystems Programs.

\section{Literature Cited}

Andersson, S., M. Presson, P. Moksnes, and S. Baden. 2009. The role of the amphipod Gammarus locusta as a grazer on macroalgae in Swedish seagrass meadows. Marine Biology 156:969-981.

Arbuckle, J. L. 2009. Amos (version 18.0) Computer program. SPSS, Chicago, Illinois, USA.

Armbrust, K. L., and D. G. Crosby. 1991. Fate of carbaryl, 1naphthol, and atrazine in seawater. Pacific Science 45:314320 .

Brawley, S. H. 1992. Mesoherbivores. Pages 235-263 in D. M. John, S. J. Hawkins, and J. H. Price, editors. Plant-animal interactions in the marine benthos. Systematics Association Special Volume 46. Clarendon Press, Oxford, UK.

Cardoso, P. G., M. A. Pardal, A. I. Lillebo, S. M. Ferreira, D. Raffaelli, and J. C. Marques. 2004. Dynamic changes in seagrass assemblages under eutrophication and implications for recovery. Marine Ecology Progress Series 302:233-248.

Carpenter, R. C. 1986. Partitioning herbivory and its effects on coral reef algal communities. Ecological Monographs 56:345-363.

Carpenter, S. R. 1996. Microcosm experiments have limited relevance for community and ecosystem ecology. Ecology 77:677-680.

Carpenter, S. R. 1999. Microcosm experiments have limited relevance for community and ecosystem ecology: reply. Ecology 80:1085-1088.

Cebrián, J. 1999. Patterns in the fate of production in plant communities. American Naturalist 154:449-468.

Cloern, J. E. 2001. Our evolving conceptual model of the coastal eutrophication problem. Marine Ecology Progress Series 210:223-253.

Connell, S. D. 1997. Exclusion of predatory fish on a coral reef: the anticipation, pre-emption and evaluation of some caging artefacts. Journal of Experimental Marine Biology and Ecology 213:181-198.

Cook, K., M. A. Vanderklift, and A. G. B. Poore. 2011. Strong effects of herbivorous amphipods on epiphyte biomass in a temperate seagrass meadow. Marine Ecology Progress Series 442:263-269.

Costanza, R., et al. 1997. The value of the world's ecosystem services and natural capital. Nature 387:253-260.

Davenport, A. C., and T. W. Anderson. 2007. Positive indirect effects of reef fishes on kelp performance: the importance of mesograzers. Ecology 88:1548-1561.

Douglass, J. G., J. E. Duffy, A. C. Spivak, and J. P. Richardson. 2007. Nutrient versus consumer control of community structure in a Chesapeake Bay eelgrass habitat. Marine Ecology Progress Series 348:71-83.

Douglass, J. G., K. E. France, J. P. Richardson, and J. E. Duffy. 2010. Seasonal and interannual change in a Chesapeake Bay eelgrass community: insights into biotic and abiotic control of community structure. Limnology and Oceanography 55:1499-1520.

Drenner, R. W., and A. Mazumder. 1999. Microcosm experiments have limited relevance for community and ecosystem ecology: comment. Ecology 80:1081-1085.

Duffy, J. E., and M. E. Hay. 2000. Strong impacts of grazing amphipods on the organization of a benthic community. Ecological Monographs 70:237-263.

Duffy, J. E., J. P. Richardson, and K. E. France. 2005. Ecosystem consequences of diversity depend on food chain length in estuarine vegetation. Ecology Letters 8:301-309.

Dumbauld, B. R., K. M. Brooks, and M. H. Posey. 2001. Response of an estuarine benthic community to application of the pesticide carbaryl and cultivation of Pacific oysters (Crassostrea gigas) in Willapa Bay, Washington. Marine Pollution Bulletin 42:826-844.

Edgar, G. J., and M. Aoki. 1993. Resource limitation and fish predation: their importance to mobile epifauna associated with Japanese Sargassum. Oecologia 95:122-133.

Edgar, G. J., and C. Shaw. 1995. The production and trophic ecology of shallow-water fish assemblages in southern Australia. III. General relationships between sediments, seagrasses, invertebrates and fishes. Journal of Experimental Marine Biology and Ecology 194:107-131.

EPA. 2011. Pesticide industry sales and usage: 2006 and 2007 market estimates. U.S. Environmental Protection Agency, Washington, D.C., USA.

Grace, J. B. 2006. Structural equation modeling and natural systems. Cambridge University Press, Cambridge, UK.

Grace, J. B., and K. A. Bollen. 2005. Interpreting the results from multiple regression and structural equation models. Bulletin of the Ecological Society of America 86:283-295.

Grace, J. B., D. R. Schoolmaster, Jr., G. R. Guntenspergen, A. M. Little, B. R. Mitchell, K. M. Miller, and E. W. Schweiger. 2012. Guidelines for a graph-theoretic implementation of structural equation modeling. Ecosphere 3(8):article 73.

Gruner, D. S., J. E. Smith, E. W. Seabloom, S. A. Sandin, J. T. Ngai, H. Hillebrand, W. S. Harpole, J. J. Elser, E. E. Cleland, M. E. S. Bracken, E. T. Borer, and B. M. Bolker. 2008. A cross-system synthesis of consumer and nutrient control on producer biomass. Ecology Letters 11:740-755.

Hauxwell, J., J. Cebrián, C. Furlong, and I. Valiela. 2001. Macroalgal canopies contribute to eelgrass (Zostera marina) decline in temperate estuarine ecosystems. Ecology 82:10071022 .

Heck, K. L., Jr., J. R. Pennock, J. F. Valentine, L. D. Coen, and S. A. Sklenar. 2000. Effects of nutrient enrichment and small predator density on seagrass ecosystems: an experimental assessment. Limnology and Oceanography 45:10411057.

Heck, K. L., Jr., and J. F. Valentine. 2006. Plant-herbivore interactions in seagrass meadows. Journal of Experimental Marine Biology and Ecology 330:420-436.

Heck, K. L., Jr., and J. F. Valentine. 2007. The primacy of topdown effects in shallow benthic ecosystems. Estuaries and Coasts 30:371-381.

Howard, R. K., and F. T. Short. 1986. Seagrass growth and survivorship under the influence of epiphyte grazers. Aquatic Botany 24:287-302.

Hughes, A. R., K. J. Bando, L. F. Rodriguez, and S. L. Williams. 2004. Relative effects of grazers and nutrients on seagrasses: a meta-analytic approach. Marine Ecology Progress Series 282:87-99.

Lee, S. Y. 2007. Structural equation modeling: a Bayesian approach. John Wiley and Sons, West Sussex, UK. 
Lee, S. Y., and X. Y. Song. 2004. Evaluation of the Bayesian and maximum likelihood approaches in analyzing structural equation models with small sample sizes. Multivariate Behavioral Research 39:653-686.

Miller, L. P., and B. Gaylord. 2007. Barriers to flow: the effect of experimental cage structures on water velocities in highenergy subtidal and intertidal environments. Journal of Experimental Marine Biology and Ecology 344:215-228.

Moksnes, P., M. Gullström, K. Tryman, and S. Baden. 2008. Trophic cascades in a temperate seagrass community. Oikos 117:763-777.

Moore, K. A., and J. C. Jarvis. 2008. Environmental factors affecting recent summertime eelgrass diebacks in the lower Chesapeake Bay: implications for long-term persistence. Journal of Coastal Research 55:135-147.

Neckles, H. A., R. L. Wetzel, and R. J. Orth. 1993. Relative effects of nutrient enrichment and grazing on epiphytemacrophyte (Zostera marina L.) dynamics. Oecologia 93:285-295.

Nelson, W. G. 1979. An analysis of structural patterns in an eelgrass (Zostera marina L.) amphipod community. Journal of Experimental Marine Biology and Ecology 39:231-264.

Orbita, M. L. S., and H. Mukai. 2009. Effects of epiphyte density on seagrass leaf turnover rate. Philippine Journal of Science 138:75-80.

Orth, R. J., et al. 2006. A global crisis for seagrass ecosystems. BioScience 56:987-996.

Orth, R. J., K. L. Heck, Jr., and J. van Montfrans. 1984. Faunal communities in seagrass beds: a review of the influence of plant structure and prey characteristics on predator-prey relationships. Estuaries 7:339-350.

Orth, R. J., and K. A. Moore. 1986. Seasonal and year-to-year variations in the growth of Zostera marina L. (eelgrass) in the lower Chesapeake Bay. Aquatic Botany 24:335-341.

Pinheiro, J. C., and D. M. Bates. 2000. Mixed-effects models in S and S-Plus. Springer-Verlag, New York, New York, USA.

Poore, A. G. B., A. H. Campbell, and P. D. Steinberg. 2009. Natural densities of mesograzers fail to limit growth of macroalgae or their epiphytes in a temperate algal bed. Journal of Ecology 97:164-175.

R Development Core Team. 2011. R version 2.11.1. R Project for Statistical Computing, Vienna, Austria. www.r-project. org
Sand-Jensen, K. 1977. Effect of epiphytes on eelgrass photosynthesis. Aquatic Botany 3:55-63.

Shurin, J. B., E. T. Borer, E. W. Seabloom, K. Anderson, C. A. Blanchette, B. Broitman, S. D. Cooper, and B. S. Halpern. 2002. A cross-ecosystem comparison of the strength of trophic cascades. Ecology Letters 5:785-791.

Spivak, A. C., E. A. Canuel, J. E. Duffy, and J. P. Richardson. 2009. Nutrient enrichment and food web composition affect ecosystem metabolism in an experimental seagrass habitat. PLoS ONE 4:e7473.

Taylor, R. B. 1998. Density, biomass and productivity of animals in four subtidal rocky reef habitats: the importance of small mobile invertebrates. Marine Ecology Progress Series 172:37-51.

Valentine, J. F., and J. E. Duffy. 2006. The central role of grazing in seagrass ecology. Pages 463-501 in A. W. D. Larkum, R. J. Orth, and C. M. Duarte, editors. Seagrasses: biology, ecology and conservation. Springer, Dordrecht, The Netherlands.

van Montfrans, J., R. L. Wetzel, and R. J. Orth. 1984. Epiphyte-grazer relationships in seagrass meadows: consequences for seagrass growth and production. Estuaries 7:289-309.

Virnstein, R. W. 1978. Predator caging experiments in soft sediments: caution advised. Pages 261-273 in M. L. Wiley, editor. Estuarine interactions. Academic Press, New York, New York, USA.

Virnstein, R. W., and R. K. Howard. 1987. Motile epifauna of marine macrophytes in the Indian River Lagoon, Florida. II. Comparisons between drift algae and three species of seagrasses. Bulletin of Marine Science 41:13-26.

Williams, S. L., and K. L. Heck, Jr. 2001. Seagrass community ecology. Pages 317-337 in M. D. Bertness, M. E. Hay, and S. D. Gaines, editors. Marine community ecology. Sinauer Associates, Sunderland, Massachusetts, USA.

Worm, B., H. K. Lotze, and U. Sommer. 2000. Coastal food web structure, carbon storage, and nitrogen retention regulated by consumer pressure and nutrient loading. Limnology and Oceanography 45:339-349.

Zieman, J. C. 1974. Methods for the study of the growth and production of turtle grass, Thalassia testudinum König. Aquaculture 4:139-143.

\section{Supplemental Material}

Appendix A

Methods and results of pilot experiment testing the effectiveness of chemical deterrent (Ecological Archives E094-042-A1).

\section{Appendix B}

Additional results from the fall experiment: full time series of mesograzers and local predator density (Ecological Archives E094-042-A2).

\section{Appendix C}

Additional results from the summer experiment: full time series of mesograzers and epiphytes, mesograzer community analysis, and estimation of effects of macrophytes on mesograzers (Ecological Archives E094-042-A3).

\section{Appendix D}

Background conditions in the York River estuary and experimental estimate of nutrient loading (Ecological Archives E094-042-A4).

\section{Appendix E}

Additional structural equation modeling results, including discussion of the development of models presented in the text and a model not shown in the text (Ecological Archives E094-042-A5). 